\title{
Medical Error Status of Nurses and Midwives Work in Gynecology and Obstetrics Clinics and Their Opinions About the Reasons
}

\section{Kadın Doğum Kliniklerinde Çalışan Hemşire ve Ebelerin Tıbbi Hata Yapma Durumları ve Nedenlerine iliş̧kin Görüşleri}

(D) Meltem UĞURLU, iD Gülşen VURAL

${ }_{1}$ University of Health Science Turkey, Gülhane Faculty of Health Science Department of Midwifery, Ankara, Turkey

${ }^{2}$ Yakın Doğu University, Division of Nursing, Lefkoşa, Kuzey Kıbrıs T.C.

\section{ABSTRACT}

Objective: To determine the medical errors of nurses and midwives work in gynecology and obstetric services and their opinions about the reasons of medical errors.

Methods: The sample of this study consisted of 365 nurses and midwives working in gynecology\&obstetrics services of nine hospitals in a city of Turkey. Ethics committee and institution permissions were obtained for the study. Data were collected using a form developed by the researchers according to literature.

Results: It was determined that $14.2 \%$ of the nurses and midwives did medical errors, the most common errors were medication (54.5\%) and communication (18.3\%) errors. Nurses and midwives stated that the insufficient number of health care workers, excessive workload, carelessness, neglect and lack of information were very important reasons of medical errors. There was a statistically significant relationship between the status of medical errors of nurses and midwives and their age, working year in profession and the number of patients they were responsible for care $(\mathrm{p}<0.05)$.

Conclusion: It is important to reduce medical errors that cause significant problems for the health system, patients and health care personnel. For this purpose, it is considered important to include medical errors in the vocational and in-service trainings of nurses

\section{ÖZ}

Amaç: Araştırma, kadın doğum kliniklerinde çalışan hemşire ve ebelerin tıbbi hata yapma durumları ve tıbbi hata nedenlerine ilişkin görüşlerinin belirlenmesi amacıyla yapılmıştır.

Yöntemler: Tanımlayıcı olarak yapılan çalışmanın örneklemini Türkiye'nin bir ilinde yer alan dokuz hastanenin kadın doğum kliniklerinde çalışan 365 hemşire ve ebe oluşturmuştur. Araştırma için etik kurul ve kurum izinleri alınmıştır. Veriler araştırmacı tarafından literatür doğrultusunda geliştirilen anket formu ile toplanmıştır.

Bulgular: Çalışmamızda hemşire ve ebelerin \%14,2'sinin tıbbi hata yaptığı, en sık ilaç uygulama $(\% 54,5)$ ve iletişim $(\% 18,3)$ hatası yaptıkları belirlenmiştir. Hemşire ve ebeler tıbbi hata nedenleri arasında; sağlık çalışanı sayısının yetersizliği, aşırı iş yükü, dikkatsizlik, ihmal ve bilgi eksikliğini önemli olarak belirtmiştir. Hemşire ve ebelerin tıbbi hata yapma durumları ile yaş, meslekte çalışma yılı ve bakım verdikleri hasta sayısı arasında istatistiksel olarak anlamlı ilişki bulunmuştur $(\mathrm{p}<0,05)$.

Sonuç: Sağlık sistemi, hasta ve sağlık personeli açısından önemli sorunlara yol açan tıbbi hataların azaltılması önem taşımaktadır. Bunun için sağlık bakım hizmetlerinde önemli rolleri olan hemşire ve ebelerin mesleki ve hizmet içi eğitimlerinde tıbbi
Address for Correspondence: Meltem UĞURLU, University of Health Science Turkey, Gülhane Faculty of Health Science Department of Midwifery, Ankara, Turkey

E-mail: meltemugurlu17@gmail.com ORCID ID: orcid.org/0000-0002-9183-219X

Cite this article as: Uğurlu M, Vural G. Medical Error Status of Nurses and Midwives Work in Gynecology and Obstetrics Clinics and Their Opinions About the Reasons. Bezmialem Science 2020;8(4):403-410.
Received: 21.06 .2019

Accepted: 17.12 .2019 
and midwives, to provide orientation of the newly graduated nurses to the clinic they work, and to ensure the corporate culture where medical errors are reported without hesitation.

Keywords: Medical errors, nurses, midwifery, malpractice hatalara yer verilmesi, yeni mezun hemşirelerin çalıştıkları birime oryantasyonunun sağlanması, tıbbi hataların çekinmeden bildirildiği kurum kültürünün sağlanması konularının önemli olduğu düşünülmektedir.

Anahtar Sözcükler: Tibbi hata, hemşire, ebe, malpraktis

\section{Introduction}

Medical errors are becoming a growing problem every day due to changing and developing health needs. Medical error is defined as the harm of the patient as a result of the inappropriate and unethical behavior of a healthcare professional, inadequate and negligent behavior in professional practice $(1,2)$. It is noted that the majority of medical errors are preventable $(3,4)$. In USA, medical errors cause about $\$ 20$ billion in additional costs and about 100,000 deaths each year (5).

Although medical errors are considered a major problem for the entire medical team, they are more important for nurses and midwives who have important roles in patient care $(6,7)$. Research conducted on this subject in Turkey shows that a significant part of medical errors occur in obstetrics clinics $(8,9)$. It is stated that $30 \%$ of the files asked for opinions from the forensic institution in terms of the presence of medical errors are related to obstetrics and gynecology, and 90\% of them are caused by complaints about pregnancy follow-up and births (8).

In the literature, medical errors that nurses and midwives most often make are noted as errors in drug administration, errors in material use and communication, insufficient patient monitoring, and hospital infections $(2,4)$. Causes of medical errors in nurses and midwives are; lack of skills and training, lack of attention, neglect, fatigue, irregular working hours, communication problems, and large number of patients $(4,10,11)$.

Medical errors cause serious problems for the healthcare system, patients and healthcare personnel, and cause problems such as a decrease in the quality of care in the healthcare system, an increase in costs and a shaken trust in the healthcare institution. Death, organ loss, severe pain, psychological disorders, financial loss and similar damages may occur in patients. Medical errors cause problems such as burnout, guilt, low performance, compensation or trial by imprisonment in healthcare personnel $(3,7,8)$. It is stated that medical errors, which are mostly considered to be preventable, cause an additional cost of \$ 8.8-15 million per year (4). Because the culture of patient safety in hospitals in Turkey has not developed, the consequences of medical errors cannot be known for sure, but it is estimated that they are similar with the countries of the world (12).

Although there are many studies of medical errors made by nurses in the literature, studies of medical errors made by nurses and midwives working in obstetrics clinics have not been reached. For this reason, this research was conducted to determine the opinions of nurses and midwives working in obstetrics clinics about the medical errors, their causes and the severity of medical errors.

\section{Method}

This descriptive and cross-sectional study was conducted in the maternity clinics of 6 training and research hospitals, 2 universities and one state hospital located in the center of a city in Turkey (high-risk pregnancy, delivery room, operating room, postpartum, gynecology, and perinatology, in vitro fertilization). A total of 426 nurses and midwives working in the specified clinics made up the universe of the study. In the study, the entire universe was included in the sample selection. But of the 426 nurses and midwives, 30 did not agree to participate in the study, 26 were on annual leave or assignment, and 11 were not included in the study due to incomplete completion of the survey, and the study was conducted with a total of 365 (85.6\%) nurses and midwives. Data collection took five months. The criteria for inclusion in the study were to work in obstetric clinics, to be literate in Turkish and to volunteer to participate in the study.

A questionnaire prepared by the researcher by scanning the literature and supported by expert opinion was used when collecting data. In the first part of the questionnaire, there were 21 questions about the socio-demographic characteristics of nurses and midwives, as well as medical errors and their consequences. In the second part, a five-part likert-type questionnaire consisting of 18 questions aimed at determining the views of nurses and midwives on the importance of the causes of medical errors was applied. The researcher asked nurses and midwives to complete the questionnaire by going to the units where they worked, and participants took an average of 10-15 minutes to complete the questionnaire.

Before the questionnaire forms were applied, nurses and midwives were informed about the research and informed consent was obtained. The study was approved by Gazi University Clinical Research Ethics Committee with Decision No. 122 dated 27.04.2011. In addition, written permissions were obtained from the health directorate of the province where the study was conducted and from the research and application centers of hospitals.

Data were evaluated using SPSS 15.0 (SPSS Inc. Chicago, IL, USA). Descriptive statistics were evaluated by number, percentile and Chi-square tests. Logistic regression analysis was performed to determine the risk factors affecting medical error. $\mathrm{P}<0.05$ was accepted as the statistical significance value in the comparison of groups. 


\section{Results}

Of the study participants, $58.1 \%$ were nurses and $41.9 \%$ were midwives. Of nurses and midwives, $68.7 \%$ were 31 years old or older, $16.5 \%$ were in the $26-30$ age group and $14.8 \%$ were 25 years old or younger. It was determined that $51 \%$ of nurses and midwives were high school or associate degree graduates, and $49 \%$ were undergraduate or had higher level of education. The proportion of nurses and midwives who were married was $78.4 \%$. Of nurses and midwives, $38.1 \%$ worked in the postpartum service, $90.7 \%$ worked as a clinical nurse or midwife, $9.3 \%$ worked as a responsible or training nurse or midwife, and $63.8 \%$ worked for 10 years or more. Of nurses and midwives, $54.2 \%$ stated that they worked in the unit for $2-5$ years, $54.2 \%$ worked more than 40 hours per week and $66.8 \%$ worked an average of eight hours per day. It was found that $44.3 \%$ of nurses and midwives worked in shifts and $46.6 \%$ had $6-10$ duties a month. It was determined that $27.6 \%$ of nurses and midwives cared for an average of $11-15$ patients daily, and $27.6 \%$ cared for over 21 patients.

Of nurses and midwives, $14.2 \%$ stated that they had made medical errors. Nurses and midwives most often stated their medical errors as drug administration (54.5\%), communication (18.3\%), follow-up (16.8\%) and other (10.4\%) (incorrect or incomplete material use, recording error and infection). Of nurses and midwives, $65.4 \%$ who made medical errors stated that they reported their errors after medical errors. They stated that $57.1 \%$ of them reported to team members, $38.1 \%$ to hospital administration and $4.8 \%$ to patients. All of the nurses and midwives who made medical errors stated that patients were not harmed after the incident.

Almost all nurses and midwives stated that carelessness (98.6\%), neglect/sloppiness (97\%) and lack of information (97\%) were the most important reasons for medical errors caused by personal reasons. Almost all nurses and midwives expressed that number of health workers (96.5\%) and excessive workload (96.5\%) were very important among the reasons for medical errors caused by the institution (Table 1).

A statistically significant difference was found between the age groups of nurses and midwives, the years of working in the profession, the number of patients they were responsible for providing care, and the situations of making medical mistakes ( $p<0.05$ ). It was determined that the educational status of the nurses and midwives, the duration of working in the unit they were in, the number of monthly shifts, weekly and daily working hours and working patterns did not affect doing medical error (p>0.05) (Table 2).

\section{Table 1. Distribution of opinions of nurses and midwives regarding the importance of the causes of medical errors ( $n=365$ )}

\section{Causes of medical errors}

\section{Institutional causes}

Insufficient number of healthcare professionals

Excessive workload/inability to spare time for the patient/excessive number of patients

Inadequate registration system

Lack of supervision

Irregular working hours

Problems with the devices used (not working, broken, no device)

Unfavorable physical conditions (ventilation, light, temperature, noise)

Insufficient vocational and in-service training

Undetermined task definitions

Individual causes

Negligence /sloppiness

Lack of skills (lack of knowledge on the use of new tools)

Lack of experience

Carelessness

Lack of self-renewal and development

Not predisposed to teamwork

Lack of in-team communication

Inability to communicate with the patient

Lack of information (inability to treat and care the patient/not knowing the principles and procedures of treatment)

\begin{tabular}{|l|l|l|l|l|l|}
$\begin{array}{l}\text { Not important/ } \\
\text { Less important * }\end{array}$ & \multicolumn{2}{|c}{$\begin{array}{l}\text { Moderately } \\
\text { important }\end{array}$} & \multicolumn{2}{l|}{$\begin{array}{l}\text { Important/ } \\
\text { Very important* }\end{array}$} \\
\hline $\mathbf{n}$ & $\%$ & $\mathbf{n}$ & $\%$ & $\mathbf{n}$ & $\%$ \\
\hline 3 & 0.8 & 10 & 2.7 & 352 & 96.5 \\
\hline 5 & 1.4 & 11 & 3.0 & 349 & 95.6 \\
\hline 22 & 6.0 & 32 & 8.8 & 311 & 85.2 \\
\hline 38 & 10.5 & 41 & 11.2 & 286 & 78.3 \\
\hline 19 & 5.2 & 24 & 6.6 & 322 & 88.2 \\
\hline 16 & 4.4 & 16 & 4.4 & 333 & 91.2 \\
\hline 20 & 4.6 & 25 & 6.8 & 320 & 88.7 \\
\hline 17 & 4.6 & 24 & 6.6 & 324 & 88.7 \\
\hline 5 & 1.4 & 15 & 4.1 & 345 & 94.5 \\
\hline & & & & & \\
\hline 5 & 1.4 & 6 & 1.6 & 354 & 97.0 \\
\hline 5 & 1.4 & 16 & 4.3 & 344 & 94.3 \\
\hline 3 & 0.8 & 22 & 6.0 & 340 & 93.2 \\
\hline 1 & 0.3 & 4 & 1.1 & 360 & 98.6 \\
\hline 3 & 0.8 & 16 & 4.4 & 346 & 94.8 \\
\hline 7 & 1.9 & 22 & 6.0 & 336 & 92.1 \\
\hline 6 & 1.6 & 23 & 6.3 & 336 & 92.1 \\
\hline 9 & 2.4 & 24 & 6.6 & 332 & 91.0 \\
\hline 2 & 0.5 & 9 & 2.5 & 354 & 97.0 \\
\hline
\end{tabular}

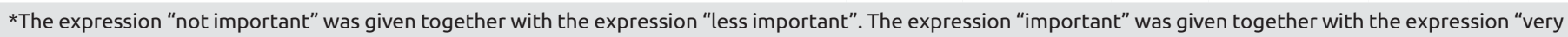
important"; n=365 
Table 2. Distribution of medical error states according to sociodemographic characteristics of nurses and midwives $(n=365)$

\begin{tabular}{|c|c|c|c|c|c|c|}
\hline \multirow[b]{2}{*}{ Age groups } & \multicolumn{2}{|c|}{$\begin{array}{l}\text { Medical error } \\
\text { maker } \\
n=52\end{array}$} & \multicolumn{2}{|c|}{$\begin{array}{l}\text { Medical } \\
\text { error-free } \\
n=313\end{array}$} & \multirow[t]{2}{*}{$\chi^{2}$} & \multirow{2}{*}{$\begin{array}{l}\mathrm{P} \\
\text { value }\end{array}$} \\
\hline & $\mathbf{n}$ & $\%$ & n & $\%$ & & \\
\hline$\leq 25$ years & 14 & 25.9 & 40 & 74.1 & & \\
\hline $26-30$ years & 16 & 26.7 & 44 & 73.3 & 19.779 & 0.001 \\
\hline$\geq 31$ years & 22 & 8.8 & 229 & 91.2 & & \\
\hline \multicolumn{7}{|l|}{ Education status } \\
\hline $\begin{array}{l}\text { Health vocational } \\
\text { high school/ } \\
\text { associate degree }\end{array}$ & 20 & 10.7 & 166 & 89.3 & \multirow[t]{2}{*}{3.790} & \multirow[t]{2}{*}{0.052} \\
\hline License or above & 32 & 17.9 & 147 & 82.1 & & \\
\hline \multicolumn{7}{|c|}{ Year of working in the unit } \\
\hline 0-1 уеаг & 21 & 18.9 & 90 & 81.1 & \multirow{3}{*}{3.559} & \multirow{3}{*}{0.175} \\
\hline $2-5$ years & 26 & 13.1 & 172 & 86.9 & & \\
\hline$\geq 6$ years & 5 & 8.9 & 51 & 91.1 & & \\
\hline \multicolumn{7}{|c|}{ Years of work in the profession } \\
\hline$\leq 4$ years & 17 & 27.4 & 45 & 72.6 & \multirow{3}{*}{12.822} & \multirow{3}{*}{0.003} \\
\hline $5-9$ years & 12 & 17.1 & 58 & 82.9 & & \\
\hline$\geq 10$ years & 23 & 9.9 & 210 & 90.1 & & \\
\hline \multicolumn{7}{|c|}{ Working hours per week } \\
\hline$\leq 40$ hours & 23 & 13.8 & 144 & 86.2 & \multirow{2}{*}{0.057} & \multirow{2}{*}{0.812} \\
\hline$\geq 41$ hours & 29 & 14.6 & 169 & 85.4 & & \\
\hline \multicolumn{7}{|c|}{ Daily working hours } \\
\hline 8 hours & 36 & 14.8 & 207 & 85.2 & \multirow{2}{*}{0.167} & \multirow{2}{*}{0.683} \\
\hline$\geq 9$ hours & 16 & 13.2 & 106 & 86.8 & & \\
\hline \multicolumn{7}{|c|}{ Number of duties per month * } \\
\hline $1-5$ & 7 & 15.9 & 37 & 84.1 & \multirow{3}{*}{0.478} & \multirow{3}{*}{0.787} \\
\hline $6-10$ & 26 & 15.3 & 144 & 84.7 & & \\
\hline$\geq 11$ & 7 & 11.9 & 52 & 88.1 & & \\
\hline \multicolumn{7}{|l|}{ Type of working } \\
\hline Day & 14 & 12.8 & 95 & 87.2 & \multirow{3}{*}{5.127} & \multirow{3}{*}{0.077} \\
\hline Night (duty) & 8 & 8.5 & 86 & 91.5 & & \\
\hline Shift & 30 & 18.5 & 132 & 81.5 & & \\
\hline
\end{tabular}

The number of patients they were responsible for providing care to

\begin{tabular}{l|l|l|l|l|l|l|}
\hline $1-5$ & - & - & 14 & 100 & & \\
$6-10$ & 9 & 15.2 & 50 & 84.8 & & \\
$11-15$ & 14 & 13.9 & 87 & 86.1 & 10.532 & 0.012 \\
$16-20$ & 6 & 6.7 & 84 & 93.3 & & \\
$\geq 21$ & 23 & 22.7 & 78 & 77.3 & & \\
\hline
\end{tabular}

* Only nurses and midwives who were on duty were assessed. $\chi 2=$ Chi-square test; $n=365 ; p<0.05$ was accepted as statistically significant

In Table 3, multivariate logistic regression analysis performed to determine independent risk factors affecting medical error is presented. The number of working years in the profession and in the current unit, shifts, the number of patients cared for, and age which were considered to increase the risk of medical errors, were
Table 3. Evaluation of factors affecting medical error using logistic regression model

\begin{tabular}{l|l|l|l|l|}
$\begin{array}{l}\text { Variable } \\
\text { (Reference) }\end{array}$ & OR & $\begin{array}{l}\text { Confidence } \\
\text { interval }\end{array}$ & p value \\
\hline Age & 26-30 years & 0.846 & $0.346-2.067$ & 0.714 \\
\hline $\begin{array}{l}\text { ( } 25 \text { years) } \\
\text { Type of working }\end{array}$ & Night & 0.287 & $0.304-0.789$ & 0.017 \\
\hline $\begin{array}{l}\text { (Day) } \\
\text { Mixed }\end{array}$ & 0.802 & $0.373-1.726$ & 0.573 \\
\hline
\end{tabular}

$\mathrm{n}=365 ;$ OR: Odds ratio

*The number of patients given care was determined as one of the factors affecting the medical error status, but due to the insufficient number of participants in the subgroups, no value could be given regarding the risk

included in the model. According to the model obtained as a result of multivariate analysis; it was found that the age, working style and the number of patients who were given care affected the condition of making medical errors, but the working year in the profession and in the current unit did not. According to the results of the analysis, the risk of medical errors was statistically reduced at the age of 31 or over compared to the age of 25 or younger $(\mathrm{OR}=0.188, \mathrm{p}<0.001)$, while the decrease in the $26-30$ age group was not statistically significant $(\mathrm{OR}=0.846, \mathrm{p}=0.714)$. When the risk of medical error was examined according to the shifts in which nurses and midwives worked, the risk of medical errors was statistically significantly reduced in night shift workers compared to daytime work $(\mathrm{OR}=0.287, \mathrm{p}=0.017)$, while the decrease observed in mixed shifts $(\mathrm{OR}=0.802, \mathrm{p}=0.573)$ was not statistically significant.

\section{Discussion}

Medical errors are seen at different rates in the world and continue to exist as an important problem. In our study, approximately one fifth of nurses and midwives stated that they made medical errors. The rate of making medical errors was $13.7 \%$ in the study by Er and Altuntaş (6), 42.9\% in the study by Külcü and Yiğit (13), 19\% in the study by Hwang and Park (14), $64.5 \%$ in the study by Cheragi et al. (15), $42.1 \%$ in the study by Bayazidi et al. (16) and 30\% in the study by Balas et al. (17). It is seen in the literature that there are findings similar and dissimilar to our results regarding medical errors. It is stated that the approach of the healthcare personnel to reporting medical errors is influenced by the patient safety culture in that hospital (10). It is thought that the differences presented above regarding the rate of medical errors may be due to safety culture and similar situations.

More than half of the nurses and midwives stated that the medical errors they made were medication errors. Similar to our results, Yücesan and Alkaya (4) and Çırpı et al. (18) stated in their study that nurses mostly encountered medication errors. In the study by Mrayyan et al. (19), approximately half of the nurses reported medication administration errors. The reasons such as the need for intense attention in drug administration, the availability of too many risky drugs, the high number of patients in the wards put nurses and midwives in a risky situation in terms of drug administration. 
In our study, nurses and midwives stated that they made communication errors most frequently after medication administration errors. In the study of Yiğitbaş et al. (20), it was determined that nurses got the highest score from the communication sub-dimension after medication and transfusion errors in the medical error tendency scale. Cebeci et al. (21) stated that the nurses got the highest score from the communication sub-dimension in medical error tendency scale. Külcü et al. (13) stated that they got the lowest score from the communication sub-dimension. In the systematic review by Keers et al. (22), when the underlying causes of medication administration errors were examined, it was stated that more than half of them were factors related to communication. Similarly, in a study where Manias (23) examined 4008 medication errors that occurred in a pediatric hospital over a 5 -year period, it was determined that $83.3 \%$ of them were related to communication. It is seen that the result obtained from our research is similar to the literature. In line with these studies, considering that medication errors and communication errors are closely related and the most common errors, strengthening communication will contribute to the prevention of both medication and communication-related medical errors. Joint Commission emphasized the importance of both issues as "increasing the efficiency of communication among caregivers" and "increasing drug use safety" among the national patient safety targets of 2018 (24). Tshiamo et al. (25) emphasized the importance of strengthening the nursing curriculum in preventing medication errors and suggested that medication errors should be included in both undergraduate and postgraduate periods.

In order to reduce and prevent medical errors, a system where employees can report medical errors without fear of punishment should be established (9). In our study, more than half of the nurses and midwives who made medical errors stated that they reported after medical errors. Nurses have difficulties in reporting medication errors due to reasons such as taking disciplinary punishment or fear of being fired (19). Therefore, it is important to create a corporate culture where nurses and midwives can report medical errors without hesitation. In our study, more than half of those who reported medical errors reported verbally to team members, less than half reported to the senior management, and a very small part reported to the patients. Similarly, Er and Altuntaş (7) reported that more than half of the nurses and Mrayyan et al. (19) reported that approximately half of the nurses reported their medical errors, and Bayazidi et al. (16) reported that nurses reported less medical errors than they did. Garbutt et al. (26) stated that more than half of the physicians $(72 \%)$ shared medical errors only with team members. Çırpı et al. stated that $60 \%$ of the nurses made written and 40\% verbal reporting (18). Kilıç and Elbaş stated in their study that $38.2 \%$ of the nurses made written and $30.9 \%$ verbal reporting (27). Cohen stated that $18 \%$ of nurses always reported medical errors to patients (28). In the study conducted by Dursun et al., it was stated that a very significant portion of the participants $(71.3 \%)$ did not report any incident that could endanger patient safety (29). These results showed that although medical error reports were made in our study, written reporting was not sufficient and the reportings made to patients were insufficient. Reporting medical errors is very important in terms of reducing the frequency of errors, understanding their causes, and improving patient safety by learning from errors (27). The most important obstacles to nurses' error reporting in studies are reported as managerial factors, fear of legal problems, inappropriate reactions of managers, fear of disciplinary action, fear of patient complaints, fear of losing license, and difficulty in bringing up undesirable events $(19,30,31)$. For this reason, it is important for hospitals to improve the culture of patient safety, to inform the members of the healthcare team, to make the error reporting systems comfortable for the staff and to introduce them. It is thought that it is important for hospitals to develop a solution-oriented system by adopting a non-judgmental/nonpunitive attitude towards employees reporting errors.

Although there are studies in the literature stating that medical errors result in death or serious harm $(32,33)$, all of the nurses and midwives in our study stated that patients were not harmed as a result of their medical error. It is thought that nurses and midwives avoid disclosing the harms of the patients because of the fear of being sued, of losing professional reputation and losing the trust of healthcare team members. For this reason, it is thought that it is important to create a system where all members of the healthcare team can report medical errors without fear, and that the system should be organized in a way that prevents medical errors.

Medical errors in health care occur due to institutional and personal reasons. Almost all of the nurses and midwives in our study stated that carelessness, negligence and carelessness were important personal causes of medical errors. Shahrokhi et al. (34) and Hicks et al. (35) found that medical errors made by nurses mostly stemmed from attention deficit and fatigue. In the study of Kahriman and Öztürk, $13.7 \%$ of the nurses stated that medical errors were caused by negligence and $6.2 \%$ of them stated that medical errors were caused by carelessness (12). It is known that irregular sleep periods due to irregular and long working hours and attention deficit due to fatigue are important in the development of medical errors (36). Therefore, it is important that nurses and midwives do not work without getting enough rest. More than half of the nurses and midwives in our study work more than forty hours a week, and approximately one third of them work more than eight hours a day. These conditions increase the tendency of nurses and midwives to make medical errors. Arimura et al. stated that shift work and fatigue affect medical errors (36).

Almost all of the nurses and midwives in our study stated that the lack of information was very important among the causes of medical errors. Similarly, in the study of Er and Altuntaş, 69.5\% of the nurses stated that insufficient professional knowledge and skills caused medical errors (6). In line with these results, in order to increase the professional knowledge and skills of healthcare professionals; it is thought that it is important to ensure the standardization of the education provided at the undergraduate level firstly, and to update the information of the employees and to raise their awareness with the in-service trainings, courses and certificate programs that will be organized on this subject after graduation. 
Almost all of the nurses and midwives stated that insufficient number of healthcare professionals was very important in medical errors caused by the institution. Studies in Turkey and other countries on this issue have stated that inadequate number of nurses, burnout of nurses and excessive workload are the most important causes of medical errors $(2,4,11,12,30,37)$. Insufficient number of nurses and midwives increase the probability of medical errors due to fatigue and attention deficit together with longer working hours and excessive workload. As a result, insufficient number of nurses adversely affects patient outcomes, quality of care, patient safety, and nurses' health (38). In line with the results obtained from the study, it is thought that the opinions of nurses and midwives in Turkey regarding the causes of medical errors are similar to the literature.

It was detected that $1 / 3$ of nurses and midwives provided care to an average of $11-15$ patients in a day and $1 / 3$ to more than 21 patients in a day. We found a statistically significant relationship between the number of patients that the nurses and midwives provided care and the number of medical errors $(\mathrm{p}<0.05)$. In the literature, there are studies supporting that the probability of medical error increases as the number of patients given care increases $(11,39)$. In the study by Cho et al., covering 51 hospitals, it was found that there was a statistically significant relationship between the increase in the number of patients per nurse and unsuccessful/poor patient safety reporting and abandoning care due to insufficient/poor quality of care and lack of time (40). In addition, it is thought that with the increase in the number of patients that nurses and midwives are responsible for, fatigue and distraction occur and the possibility of medical errors increases. In a systematic review conducted on this subject, it was determined that there was strong evidence supporting the positive relationship between the negative outcomes and long working hours of nurses (41).

Almost all of the nurses and midwives (95.6\%) stated that excessive workload was very important as a cause of medical errors caused by the institution. Thirty six point four percent of nurses in the study of Alemdar and Aktaş (7), 72.8\% in the study of Kahriman and Öztürk (12), and $75.6 \%$ in the study of Er and Altuntaş (6) stated that the excessive workload was among the causes of medical errors. In our study, the rate of nurses and midwives who stated excessive workload as a cause of medical error was found to be higher than other studies on this subject.

The relationship between the ages of nurses and midwives and years of working in the profession and their status of medical error was found to be statistically significant $(\mathrm{p}<0.05)$. Koçak and Yaman (39) stated in their study that nurses mostly made medical errors in the 26-35 age group and when their professional experience was 5 years or less. In the same study, it was stated that healthcare workers who worked in the profession for 10 years or more made less medical errors (39). Similar studies on this subject found that less serious medical errors occur where there were more experienced nurses, and this was statistically significant $(38,42)$. In the study conducted by Smith et al. (37) with newly graduated nurses, it was determined that lack of communication, excessive workload and long working hours contributed to the occurrence of medical errors. It was determined that our result was similar to that of literature.

No statistically significant difference was found between the educational status of nurses and midwives and their medical errors ( $p>0.05$ ) (Table 2). Similar to our results, Sears et al. (38) stated that there was no statistically significant relationship between the training of nurses and the state of making medical errors ( $p>0.05)$. It is expected that medical errors will decrease as the education level and knowledge level increase. However, no result supporting this was obtained in our study. Other studies are recommended to be performed on this subject.

In our study, no statistically significant correlation was found between the duration of work in the unit and the number of monthly shifts and the status of making medical errors ( $p>$ 0.05). Similarly, Göktaş (43) stated that there was no statistically significant relationship between the working year and monthly number of shifts in the unit where the nurses were located, and the status of making medical errors ( $p>0.05$ ). Rogers et al. (44) found that the rate of medical errors increased in nurses working more than 12 hours a day, and determined that working more than 40-50 hours per week might cause medical errors. In the study of Izadpanah et al. (45), it was determined that the number of medication errors increased as working hours increased. However, the determination in our study that weekly and daily working hours did not affect medical errors was thoughtprovoking. Other studies are recommended to be performed on this subject. In a systematic review examining the working hours of nurses and the outcomes of patients, it was stated that more evidence was needed to say that there was a positive relationship between long working hours and negative patient outcomes (41).

No statistically significant correlation was found between the shifts in which nurses and midwives worked and their status of making medical errors ( $p>0.05$ ) (Table 2). In the study of Seki and Yamazaki (46), it was determined that there was no statistically significant difference between working in different shifts and the number of medication administration errors. In the systematic review by Bae and Fabry (41), it was stated that there was no relationship between medical errors and the shifts in which the nurses worked. Other studies are recommended to be performed on this subject.

When the factors affecting making medical errors were evaluated with logistic regression analysis in our study; it was determined that age, working style and the number of patients given care were among the factors that affected making medical errors. The relationship between age and the number of patients treated and making medical error was discussed above. In our study, when medical errors were examined according to the working styles of nurses and midwives, it was determined that those who worked in shifts, worked in days and worked in nights, respectively, made more medical errors. In a study similar to our result, it was determined that medical errors mostly occured in the morning hours (47). In contrast, Pham et al. (48) stated that the highest rate of errors occurred during the evening shift. In our research results, it was determined that nurses and midwives who worked 
in shifts (mixed day and night) made medical errors at the highest rate. This result is thought to be caused by problems such as fatigue and inattention, which develop due to irregularities in the sleep patterns of nurses and midwives who work in shifts. In the research conducted by Peker (49), it was found that not having the opportunity to rest during the shift negatively affected the level of attention. In our results, the reason for the lowest risk of making medical errors in night shift workers was that more patient hospitalizations, examinations and similar proceduress during the day shift caused distraction and concentration disturbance in nurses and midwives; and at night, the work was more routine and confounding factors were reduced, therefore, the risk of making medical errors was thought to decrease.

\section{Study Limitations}

This study was conducted with nurses and midwives working in nine hospitals located in only one city center. Nurses and midwives working in private hospitals were excluded. While interpreting our results, it should not be forgotten that there was a group of healthcare professionals working in hospitals located in a city center with a high workload.

\section{Conclusion}

In the study, it was determined that nurses and midwives most frequently made medication errors. In order to reduce medication errors, an effective reporting system should be established in hospitals and necessary measures should be taken by determining the factors that prevent medical error reporting. In addition, it is recommended to increase knowledge and awareness by emphasizing the importance of the issue in vocational and in-service trainings performed with nurses and midwives. It was determined that the medical error reporting behaviors of nurses and midwives were not sufficient and they preferred to report medical errors verbally. It is recommended to provide an institutional culture where medical errors can be reported without fear of punishment.

In the study, a significant relationship was found between the working years of nurses and midwives and their status of making medical errors. In line with this result, it is thought that newly graduated nurses and midwives, who are younger and have little professional experience, should work under the supervision of their experienced colleagues during the orientation process.

\section{Ethics}

Ethics Committee Approval: Ethics committee approval was obtained from Gazi University Clinical Research Ethics Committee with the decision dated 27.04.2011 and numbered 122.

Informed Consent: Obtained.

Peer-review: Externally and internally peer reviewed.

\section{Authorship Contribution}

Surgical and Medical Practices: M.U., Design: M.U., Concept: M.U., G.V., Data Collection or Processing: M.U., G.V.,
Analysis or Interpretation: M.U., Literature Search: M.U., G.V., Writing: M.U., G.V.

Conflict of Interest: No conflict of interest was declared by the authors.

Financial Disclosure: The authors declared that this study received no financial support.

\section{References}

1. Croke EM. Nurses, negligence and malpractice. Am J Nurs 2003;103:54-63.

2. Özata M, Altunkan H. Hastanelerde tıbbi hata görülme sıklıkları, tıbbi hata türleri ve tıbbi hata nedenlerinin belirlenmesi: konya örneği. Turkish Res J Med Stu 2010;8:100-11.

3. Annual Third. Health Grades Quality Study. 2006. Available from: URL: http://www.protectmasspatients.org/docs/ PatientSafetyInAmericanHospitalsStudy2006.pdf

4. Yücesan A, Alkaya SA. Bireylerin tıbbi hatalarla ilgili görüş ve deneyimleri. Dicle Tip Derg 2017;44:25-31.

5. Rodziewicz TL, Hipskind JE. Medical Error Prevention. StatPearls [Internet] 2019. Available from: URL: http://www.ncbi.nlm.nih.gov/ pubmed/29763131

6. Er F, Altuntaş S. Hemşirelerin tıbbi hata yapma durumları ve nedenlerine yönelik görüşlerinin belirlenmesi. JPHN 2016;3:132-9.

7. Alemdar DK, Aktaş YY. Medical error types and causes made by nurses in Turkey. TAF Prev Med Bull 2013;12:307-14.

8. Birgen N. Kadın doğum hekimliğinde medikolegal uygulamalar. Available from: URL: http://www.tjodistanbul.org/egitim/istanbulkliniklerinden/genel-jinekoloji/kadin-dogum-hekimligindemedikolegal-uygulamalar

9. Elbüken B. Sağlık profesyonellerine yönelik tıbbi uygulama hata iddiası ile yüksek sağlık şurasına gönderilen olguların irdelenmesi (Yüksek Lisans Tezi). Marmara Üniversitesi. 2010.

10. Gökdoğan F, Yorgun S. Sağlık hizmetlerinde hasta güvenliği ve hemşireler. J Anatolia Nurs Health Sci 2010;13:53-9.

11. Işık $\mathrm{O}$, Akbolat $\mathrm{M}$, Çetin $\mathrm{M}$, Çimen M. Hemşirelerin bakış açısılla tıbbi hataların değerlendirilmesi. TAF Prev Med Bull 2012;11:42130.

12. Kahriman İ, Öztürk H. Evaluating medical errors made by nurses during their diagnosis, treatment and care practices. J Clin Nurs 2016;25:2884-94.

13. Külcü DP, Yiğit R. Çocuk kliniklerinde çalışan hemşirelerin tıbbi hata yapma eğilimlerinin incelenmesi. J Anatolia Nurs Health Sci 2017;20:34-40.

14. Hwang JI, Park HA. Nurses' perception of ethical climate, medical error experience and intent-to-leave. Nurs Ethics 2014;21:28-42.

15. Cheragi MA, Manoocheri H, Mohammadnejad E, Ehsani SR. Types and causes of medication errors from nurse's viewpoint. Iran J Nurs Midwifery Res 2013;18:228-31.

16. Bayazidi S, Zarezadeh Y, Zamanzadeh V, Parvan K. Medication error reporting rate and its barriers and facilitators among nurses. J Caring Sci 2012;1:231-6. 
17. Balas MC, Scott LD, Rogers AE. The prevalence and nature of errors and near errors reported by hospital staff nurses. Appl Nurs Res 2004; 17:224-30.

18. Çırpı F, Merih YD, Kocabey MY. Hasta güvenliğine yönelik hemşirelik uygulamalarının ve hemşirelerin bu konudaki görüşlerinin belirlenmesi. Maltepe Üniv Hemş Bil San Derg 2009;2:26-34.

19. Mrayyan MT, Shishani K, Al-Faouri I. Rate, causes and reporting of medication errors in Jordan: nurses' perspectives. J Nurs Manag 2007;15:659-70.

20. Yiğitbaş Ç, Oğuzhan H, Tercan B, Bulut A, Bulut A. Hemşirelerin malpraktis ile ilgili algı, tutum ve davranışları. Anadolu Klin Tıp Bil Derg 2016;21:207-14.

21. Cebeci F, Gürsoy E, Tekingündüz S. Hemşirelerin tıbbi hata yapma eğilimlerinin belirlenmesi. Anadolu Hemş Sağ Bil Derg 2012;15:18896.

22. Keers RN, Williams SD, Cooke J, Ashcroft DM. Prevalence and nature of medication administration errors in health care settings: a systematic review of direct observational evidence. Ann Pharmacother 2013;47:237-56.

23. Manias E. Effects of interdisciplinary collaboration in hospitals on medication errors: an integrative review. Expert Opin Drug Saf 2018;17:259-75.

24. Fenner K. The Joint Commission's Hospital National Patient Safety Goals for 2018. Available from: URL: https://www.compass-clinical. com/the-joint-commission-national-patient-safety-goals-for-2018/

25. Tshiamo WB, Kgositau M, Ntsayagae E, Sabone MB. The role of nursing education in preventing medication errors in Botswana. Int $\mathrm{J}$ Africa Nurs Sci 2015;3:18-23.

26. Garbutt J, Brownstein DR, Klein EJ, Waterman A, Krauss MJ, Marcuse EK, et al. Reporting and disclosing medical errors: pediatricians' attitudes and behaviors. Arch Pediatr Adolesc Med 2007;161:179-85.

27. Kılıç HS, Elbaş NÖ. Bir eğitim ve araştırma hastanesinde çalışan hemşire ve doktorların hasta güvenliği hakkındaki bilgileri ve tıbbi hataların bildirilmesi hakkındaki görüşleri. Anadolu Hemş Sağ Bil Derg 2014;17:97-104.

28. Cohen M. Patient safety alert: "high-alert" medications and patient safety. Int J Qual Health Care 2001;13:339-40.

29. Dursun S, Bayram N, Aytaç S. Hasta güvenliği kültürü üzerine bir uygulama. Manisa

30. Celal Bayar Üniv Sos Bil Derg 2010;8:1-14.

31. Hosseinzadeh M, Ezate Aghajari P, Mahdavi N. Reasons of nurses' medication errors and perspectives of nurses on barriers of error reporting. Hayat 2012;18:66-75.

32. Bahadori M, Ravangard R, Aghili A, Sadeghifar J, Gharsi Manshadi M, Smaeilnejad J. The factors affecting the refusal of reporting on medication errors from the nurses' viewpoints: a case study in a hospital in iran. ISRN Nurs 2013;2013:876563.

33. Lamb RM, Studdert DM, Bohmer RMJ, Berwick DM, Brennan TA. Hospital disclosure practices: results of a national survey. Health Aff 2003;22:73-83.
34. Bodur S, Filiz E, Durduran Y. Sağllk personeli ve toplumun tıbbi hatalar ile ilgili görüşlerinin karşılaştırılması. Genel Tip Derg 2011;21:123-30.

35. Shahrokhi A, Ebrahimpour F, Ghodousi A. Factors effective on medication errors: a nursing view. J Res Pharm Pract 2013;2:18-23.

36. Hicks RW, Sikirica V, Nelson W, Schein JR, Cousins DD. Medication errors involving patient-controlled analgesia. Am J Health Syst Pharm 2008;65:429-40.

37. Arimura M, Imai M, Okawa M, Fujımura T, Yamada N. Sleep, mental health status, and medical errors among hospital nurses in Japan. Ind Health 2010;48:811-7.

38. Smith J, Crawford L. Medication errors and difficulty in first patient assignments of newly licensed nurses. JONAS Healthc Law Ethics Regul 2003;5:65-7.

39. Sears K, O’Brien-Pallas L, Stevens B, Murphy GT. The relationship between nursing experience and education and the occurrence of reported pediatric medication administration errors. J Pediatr Nurs 2016;31:e283-90.

40. Koçak DY, Yaman Ş. Kadın doğum kliniklerinde çalışan hemşirelerin yaptıkları ilaç hataları ve etkileyen faktörler. HEAD 2015;12:99-104.

41. Cho E, Chin DL, Kim S, Hong O. The relationships of nurse staffing level and work environment with patient adverse events. J Nurs Scholarsh 2016;48:74-82.

42. Bae SH, Fabry D. Assessing the relationships between nurse work hours/overtime and nurse and patient outcomes: systematic literature review. Nurs Outlook 2014;62:138-56.

43. Chang YK, Mark BA. Antecedents of severe and nonsevere medication errors. J Nurs Scholarsh 2009;41:70-8.

44. Göktaş S. Bir kamu hastanesinde hemşire istihdamının hasta güveliğine etkisi (Yüksek Lisans Tezi). Haliç Üniversitesi; 2007.

45. Rogers AE, Hwang W, Scott LD, Aiken LH, Dinges DF. The working hours of hospital staff nurses and patient safety. Health Aff (Millwood) 2004;23:202-12.

46. Izadpanah F, Kashani HH, Sharif MR. Preventing Medicine mistakes in pediatric and neonatal patients. J Med Life 2015;8:6-12.

47. Seki Y, Yamazaki Y. Effects of working conditions on intravenous medication errors in a japanese hospital. J Nurs Manag 2006;14:12839.

48. Khammarnia M, Ravangard R, Barfar E, Setoodehzadeh F. Medical errors and barriers to reporting in ten hospitals in southern iran. Malays J Med Sci 2015;22:57-63.

49. Pham JC, Story JL, Hicks RW, Shore AD, Morlock LL, Cheung DS, et al. National study on the frequency, types, causes, and consequences of voluntarily reported Emergency Department medication errors. J Emerg Med 2011;40:485-92.

50. Peker A. Vardiya sistemi ile çalışan hemşirelerin dikkat düzeyleri (Yüksek Lisans Tezi). Kocaeli Üniversitesi; 2009. 